\title{
Civilized Urbanity. Modernismo and the Urban Landscape.
}

\section{Civilizada Urbanidad. Modernismo y paisaje urbano.}

\section{Resumen}

En este ensayo analizaré la inserción del binomio civilización/barbarie en la literatura de los escritores modernistas. Para ello analizaré brevemente el contexto histórico tras la Independencia de las colonias y el nuevo orden neo-imperialista que, asentado en la ciudad, exigió cambios sociales, económicos y urbanísticos que afectaron a todos los estratos sociales. Seguidamente explicaré cómo se hizo frente a la formación de un nuevo ciudadano que debía seguir ciertas pautas de comportamiento para aislarse de la barbarie y el salvajismo de los lugares alejados de la metrópolis. Justificaré con ello la importancia de la llamada ciudad letrada en la formación de las nuevas naciones modernas y describiré el nacimiento del escritor modernista, autodefinido por su individualidad y por las contradicciones que entraña su escritura. Ejemplificaré mis argumentos con los textos que, nacidos en el proceso de la modernidad, reivindican la tradición negando la sociedad del utilitarismo capitalista en la que se insertan.

Palabras claves

ciudad letrada, civilización/barbarie, espacio urbano, Latinoamérica.

\begin{abstract}
In this essay, I examine the inclusion of the civilization/barbarism binary in the literature of modernistas writers. To this end, I will briefly analyze the historic contexts after the independence of the colonies and the new neo-imperialist order that settled in the city and demanded social, economic and urban changes that affected the entire social strata. At the same time, I will explain how the formation of a new citizen was undertaken, as it had to follow certain behavioral guidelines to isolate itself from barbarism and savagery of places far away from the metropolis. With it I will justify the importance of the so-called ciudad letrada (city of letters) in the formation of new modern nations and describe the birth of the
\end{abstract}


modernist writer, self-defined by its individuality and the contradictions involved in its writing. I will explain my arguments with the texts that, born in the process of modernity, claim the tradition of denying the capitalist utilitarian society into which they are inserted.

Keywords ciudad letrada, civilization/ barbarism, Urban Spaces, Latin America.

Tengo el impuro amor de las ciudades, y a este sol que ilumina las edades prefiero yo del gas las claridades. A mis sentidos lánguidos arroba, más que el olor de un bosque de caoba el ambiente enfermizo de una alcoba. Mucho más que las selvas tropicales, plácenme los sombríos arrabales que encierran las vetustas capitales [...]. Julián del Casal "En el campo" 1

The fight for independence from Spain in Latin America began in the 19th century. The uprisings that occurred in different places and different times responded in general to economic interests conveyed through the ideas of the local upper classes. They promoted the belief that monopolistic commercial relations with the Iberian Peninsula would never allow a great profit for Latin America since Spain was always favored. In addition, the issue was compounded by the interests of large European commercial firms, particularly British firms, which entered Continental Europe to expand activities supported by their government (Schütz 35).

In this context, the Latin American economy starts to link with industrialized countries with the objective of "dissipating the colonial past to set up the modern ways of life" (Romero 248), ascribing to the neo-imperialist world order. The businesses multiplied to face the demands of the international market,

${ }^{1}$ In Obra poética. La Habana: Editorial Letras Cubanas, 1982. 239. 
provoking changes in production systems and infrastructure. These changes were closely linked to the transformation of space and, in particular, of the capitals especially the ports of Río de Janeiro, Montevideo, Buenos Aires, Panamá City, Havana and San Juan de Puerto Rico - where the creation of products destined for the world market were guided. The adoption of the European way of life was proposed, transforming the face of the colonial past into the desired image of a prosperous and modern country. Haussman's Paris model favored bigger differences between the capital and the provinces, where there was still an air of "the colonial and patrician past" (Romero 249). This articulated a resistance to foreign formulas.

On par with economic and urban changes, social restructuring commenced. The new bourgeoisie had been preparing to benefit from the circumstances and were the first to assimilate the European models into their customs and crafts. They had an intermediary part in economic life that rose alongside the process of industrialization where labor was national, but capital was foreign. Further, with World War I, the bourgeois lifestyle faced more changes influenced by the need to train in new professions of the era and also to become a new type of man of letters (Romero 295).

This kind of life - baroque, bourgeois and newly rich (Salvador 285) nourished the vast production of naturalism literature and served as a framework for Modernismo. Indeed, Modernismo found its determining elements and configuration mirrored in the new, experimental design of Hispanic cities; such centers became, as Modernismo itself did, intellectual hubs where ideas germinated. The modernista writer, except in rare exceptions, lives in the city and is a citizen of the ciudad letrada (city of letters). This modern-day Babel, as Navascués (2002) called it, gazes over fields and mountains only to idealize a lost paradise, since the Arcadia does not have a place in modernity. In this way, progress is associated with the city - and with the conquest of nature as something at the service of man. In this new social consciousness, such a transfiguration 
forged a critical conscience that was legitimized in numerous speeches that underscored the civilization/barbarism dichotomy.

In a certain respects, the thought took on numerous meanings, chief among them salvajismo (savagery). Its purpose was to merely reiterate, with its own nuances, an archaic formulation that referred to a millenary ethnocentrism (Fernández Retamar 106). Such an ethnocentrism can be seen as characteristic of the underdeveloped communities that, wanting to exalt localism, rejected and denigrated the foreign: it "implies this way that the other tribes, groups and villages do not participate in the human virtues - or even in the nature [...] frequently it even leads to depriving the foreigner, making him a "ghost" or an “apparition” (Lèvi-Strauss 21).

The difference, then, did not reside in the blood but in the culture. Dating back to the sixteenth century, the term was used to designate a new reality that had accomplished utopian European expectations: the discovery of America. Either under the designation of savage, or barbarian, cultural diversity is denied in order to "throw" onto nature "everything that does not conform to the norms under which they live" (Lèvi-Strauss 20). But there was not one, but rather two encounters between America and Europe. In the second one, the one which this essay takes as its focus, it is the stumble with Western modernity that forged the barbaric image of the South America continent ${ }^{2}$. Inescapably, there was a racial component (Fernández Retamar 111) that put those who did not belong to the supposed "civilization" at a disadvantage. Further, it was a spatial factor that made the polis triumph over the immense and unknown territory of barbarism (Rama, La ciudad... 14).

That being said, Facundo by Domingo Faustino Sarmiento was the foundational text that guided the construction of the cultural imaginary of Latin American society; it also imposed the central axis of modernization: the

\footnotetext{
${ }^{2}$ In his article 'De la 'cuestión indígena' a lo 'indígena' como cuestionamiento. Hacia una crítica del latinoamericanismo, el indigenismo y el mestiz(o)aje”, Armando Muyolema examines the origin and process of conceptual, cultural and political configuration of Latin America as a cultural project of occidentalization. See References.
} 
civilization of barbarism. ${ }^{3}$ Thus, the author proposed to clearly mark the horizons of geographical and social barbarism by assuming its coexistence with imported European models:

En la República Argentina se ven a un tiempo dos civilizaciones distintas en un mismo suelo: una naciente, que sin conocimiento de lo que tiene sobre su cabeza está remedando los esfuerzos ingenuos y populares de la Edad Media; otra, que realiza los últimos resultados de la civilización europea. El siglo XIX y el XII viven juntos: el uno adentro de las ciudades, el otro de la campaña. (Sarmiento 53)

The author transfers to the American soil the corresponding metropolitan formula, of which he considers himself "reason and spokesman" (Fernández Retamar 110). He defends with it the elimination of the oral world from the tradition as a step into modernization. It is the fight between European civilization and indigenous barbarism (Sarmiento 15), that is, between the metropolitan bourgeoisie and the native habitants: gauchos, llaneros, and mestizos of the region. It is also the confrontation of two different national projects - European and American - that may blend under "la sombra de instituciones civilizadoras y libres" (Sarmiento 226).

The space where Sarmiento wants to develop his national project cannot be any other than the city, the rational space where passion can be stopped thanks to contact with civilization (Navascués 63). However, there is no direct opposition between countryside/city. It was more between mass-horde/lettered-educated, illustrated clearly by Graciela Montaldo in her study "Sujetos y espacios: las masas hispanoamericanas y la ocupación territorial” included in Navascués (62). The masses are dominated by leaders or chieftains, another element that must be destroyed by modernity, and only through education or "civilization" they can

\footnotetext{
${ }^{3}$ José Hernández did the opposite exalting the American barbarism in his Martín Fierro (1872).
} 
leave the barbaric state of being behind them to help the national project in which Sarmiento is immersed. In this way, the assimilation of cities become civilizing spots, and the "vast savage territory" had to impose the new norms - in the words of Ángel Rama, execute, the mechanisms of power of the city of letters: what was first called "evangelization" and then "education" (La ciudad...17).

In Nuestra América (1891), Martí specified that educated men were instructed in the "art of governing" so that the uncultured masses could not claim power by force. The Cuban writer rebelled against stagnant Spanish colonialism and North American imperialism defending with his texts the South America continent's autonomy to govern itself without foreign intervention, something that also consigned the cultural heritage of the country. This becomes clear in the prologue of the Poema del Niágara ${ }^{4}$ and the review of Vicente G. Quesada's book La sociedad hispanoamericana bajo la dominación española:

Tienen unos por ciencia en América, y por literatura científica y principal, el estudio minucioso de los pueblos que les apartan del origen y costumbres, y el desconocimiento punible y sistemático del país en que han de vivir. [...] pero este desdén de lo criollo, singular en quienes en lo suyo intentan influir, aunque suele ser signo por donde anuncia su aspiración descontentadiza un espíritu potente, es más a menudo prueba cierta de entendimiento segundón, que al gozo de cavar por sí en los nuevo prefiere llevar a cuestas lo que cavó otro; o prurito rural del hijastro que en la brava honra solariega suspira avinagrado por su fantástica progenie de galanas y damas palatinas, y en su inútil corazón niega a su padre (Martí, Páginas 172).

4 "Ni la originalidad literaria cabe, ni la libertad política subsiste mientras no se asegure la libertad espiritual. El primer trabajo del hombre es reconquistarse" (Martí, Páginas 35). 
Martí is already part of the Modernismo movement forged on the economic base of liberalism as a literary manifestation of the nineteenth culture regeneration. There are many definitions that have been used to describe Modernismo, particularly as it relates to its contradictions. However, for the purpose of this essay, I am interested in highlighting the one made by Roberto Brenes Mesén:

El modernismo en el arte es simplemente una manifestación de un estado del espíritu contemporáneo, de una tendencia universal cuyos orígenes se hallan profundamente arraigados en la filosofía trascendental que va conmoviendo los fundamentos de la vasta fábrica social que llamamos el mundo moderno. ${ }^{5}(663)$

This modern world is the result of the "world crisis" cited by Rama for the purpose of imperial expansion of the European industrialized powers that transfer their economic and social capital to the South America continent (Rubén Darío y el modernismo 26). In other words, besides a world of evasion comprised of great and exotic environments where swans, peacocks, satyrs and nymphs live, there is also another world of "metaphysical anguish" of social comprehension and continental worry (Gullón 15; Schulman 18). As mentioned before, these ideas are consigned under the changes being produced in the large cities with the imitation of the transformation made by Baron Haussman in the French capital.

Nonetheless, the city was not "merely Paris," but "that central city that is possible to dream from the periphery at the mercy of the excitement promoted by letters and the images" (Rama, La ciudad...116). The modernistas, as Octavio Paz indicates, "did not want to be French: they wanted to be modern" (Darío, Antología 18). In search of that purpose, they had to look to other continents. Juan Valera, in his prologue in $A z u l \ldots$, claims to have found the book "impregnated 
with cosmopolitan spirit" (Darío, Antología 40). Therefore, it is the fluctuation between the interior - the Latin American countries - and the exterior - Europe, North America- and between stagnation and movement (González 132) what creates a literature that takes on a distinctly American identity.

From another perspective, understanding Paris or London as the ideal cities in development in Europe, Rubén Darío, in his prologue to Prosas profanas, legitimized Buenos Aires as the "Cosmópolis" of Latin America. This endorsement does nothing more than confirm the need of a territory and a personal space in which to claim a "social space", an organism of high culture (González Stephan 93), which is still the elitist impulse of the ancient colonial society and serves as city-capital (Navascués 20) to the new bourgeoisie. However, eclecticism is not just part of this mutation. The new cosmopolitan classes decorated their interiors with items from other countries, which inspired many writers. The brief fragment of the poem "Neurosis" by Julián del Casal serves as an example:
Un biombo rojo de seda china
abre sus hojas en una esquina
con grullas de oro volando en cruz,
$y$ en curva mesa de fina laca
ardiente lámpara se destaca
de la que surge rosada luz (Casal 207).

This change in the interior of the house was accompanied by an alteration of customs, a modification of everyday use, and the need for consumption as a direct consequence of commercial expansion, which invaded the homes of "civilization" (Gutiérrez Girardot 71). Meanwhile, the sudden expansion suffered under the modernization and the entrance of a high number of new inhabitants, which caused consternation among those who did not abide with the new changes, 
inspiring and imposing "the modernization of the citizen's soul" (Berman 146) or in cruder terms, the "domestication of barbarism” (González Stephan 109).

The first step for training men and women capable of functioning in accordance with this new urban lifestyle was the construction of behavior models, of norms that outlined the limits and the symbolic frontiers of citizenship (Rama, La ciudad...18). Writing was charged with designing a national identification project under which everyone had to follow the rules, from the bourgeoisie to the rich, to the poor to foreigners in search of fortune (96). In this way, the bourgeois system of values exerted a "pressure of accommodation” (Gutiérrez Girardot 28), which invaded all strata of civil society. The leaders of this system, as one might expect, were not the landowners nor were they the old bourgeoisie; on the contrary, they were the new urban, business, and commercial bourgeoisie who adapted to the needs of the industrialized metropolis.

This social group was depicted by the modernista authors who focused their attention on the group's competitiveness and its subordination to materialism and everything it implied: luxury, travel, servants and a perpetual sense of nonconformity. The perfect example is the character José Asunción Silva in De sobremesa who enjoys "enervating luxury, refined comfort" (23) but never cures his melancholic state. Not even the provision of travel or ascribing to the idea of "European high culture" (Rosenberg 471) filled the emptiness they sought to replace with ostentation:

Si tú conocieras á París. Las cinco de la tarde en el Bosque: no cabe más allá. Si supieras lo que vale transitar la Avenida de los Campos Elíseos á esa hora, entre jardines, en medio de trenes lujosísimos donde tú ves las artistas, las demi-mondaines á la moda, los diputados, los embajadores, los literatos, todo el París conocido de cerca ó de lejos...! Y luego el sol, allá, detrás del Arco de Triunfo, chispeando, á un lado, sobre la cúpula de los Inválidos, y espolvoreando las avenidas, las toilettes, los árboles con su polvillo de oro... (Blanco 37-38) 
The lower strata of the society also suffered through some changes; they thought to have found the cure for all their ailments in the city. With them a new proletariat is born which was going to be the labor of industrialization (Navascués 60). As a consequence, the new neighborhoods were built to set their homes. Ramón Luz and mister Perrín illegally embark in the construction of the houses in the Blanco Fombona's novel (242), and the young José Fernández de Silva raises the possibility of a national project in which to include the Colombian peasants and those:

[...] ansiosos de nueva vida, en los puertos de la vieja Europa, de donde el hambre los arroja, en los del Japón y China, países desbordantes de población hambreada y en las amplias radas de la península índica de donde el nativo pobre, el paria desheredado, el bengalí de belleza casi femenina. (Silva 68)

This new immigration served to assist the formation of these new urban societies since many were employed in the industry at the same time as the natives -and many others arrived with sufficient capital to invest and prosper. This happens with mister Perrín -son of an English father and a Dutch motherand with Schegell -son of a German father and a Venezuelan mother- in the novel El hombre de hierro. In this narrative, Rosendo and Joaquín open a discourse regarding the role of immigration within the country, diminished by the discredit campaign of Europe and United States (Blanco 85-86).

Secularization serves as another common discourse employed by José Luis Romero in his book Latinoamérica: las ciudades y las idea. Modernization suppressed many customs that now were accepted as part of life in the provinces. Juan Valera emphasized this in Rubén Darío's poetry in his prologue Azul... (48). Meanwhile, characters such as father Iznardi Acereto -El hombre de hierro-, 
Scilly Dancourt -De sobremesa- or Laura -La rosa muerta-, ${ }^{6}$ feel troubled due to what they consider a disease that required them to search for new values. Often such values were found in spiritualism, in the occult (Gutiérrez Girardot 82) or in the work of new thinkers such as Rodó, whose Ariel was the "cure of souls" (Rama, La ciudad... 111) for youth eager for knowledge. All of this is summarized in the title of the novel by Díaz Rodríguez Ídolos rotos, or the destruction of the belief system of the modern America.

This feeling of religious crisis boosted diverse sacred modalities to compensate for the emptiness skepticism caused. In this sense, the role that writing played is notable, since it created a model that was a "deposit of forms" for the organization of the new nations (Ramos 28). The nation, as stressed by Renan, is a relatively modern concept (61), but in the period we are interested in, the emergence of players -bourgeoisie, immigrant or working-class- and their setting - the city - were the basis for the creation of an artificial nation:

Lo primero que hay que fabrica es el subsuelo, que es tierra, sino un barrizal inmundo y deleznable.

[...]-La cuestión raza, -insistió Mario, -es mucho más grave, á mi ver. Es el gran problema del país. No hay unidad de raza, y por consiguiente carecemos de ideas nacionales. [...] Pero de tres Venezolanos, blanco, indio o negro, dígase: ¿cuál es el lazo de unión, aparte el de la lengua y el de la nacionalidad? Los ideales son distintos en cada uno; lo mismo en arte, que en todo. Carecemos de alma nacional. (Blanco 258-259)

In this dream of uniformity in which the submission of "barbarism" was projected, writing is the space of the law, the authority and the power; it establishes and creates new entities. The "civilized" nation is the orderly city within the city of letters, since "the emblem that controls writing distributes,

\footnotetext{
${ }^{6}$ Also perceptible in the same title of another poem book: Prosas profanas.
} 
decides and defines - obviously for the collective imaginary - what instances or spaces will correspond to chaos, with the anti-law, with barbarism" (González Stephan 111). On the one hand, it incorporates rural and oral ways of life as emerging forms of national feeling that have been destroyed due to modernization through genres such as realism or costumbrismo. On the other hand, it confers an origin and a future ideal to the city as a frame of modernization which categorizes the countryside and the city in hierarchies, as well as the national and the cosmopolitan, the oral and the written, and the popular and the cultured.

From this perspective, Ariel will be the ideal allegory of the democratic nation of the future and of the harmonious humanity that will build the new America separate from North American utilitarianism. In front of Caliban, soul in front of body, harmony against savagism, Ariel is legitimized under "its own schedule [...] in the spirit of groups and people that are more than crowds" (Rodó 23-24). However, to carry out any civilizing program, the lettered city must become an ally, or at least an accomplice, of the leading political apparatus. From this position, it will regulate the symbolic complex of culture, disciplining the vital inclination towards the adoption of an artificial nature and codified in the letter (Rama, La ciudad... 118). In fact, dominating writing and reading is the first step to having access to the space of civilization. Hence the defense of Sarmiento, Rodó, or Martí of creating an educated society upon which to set the basis for a new civil society far away from the chaos of the empire and the calibanesque bestiality.

Not only the narrative, but also the poetry, adjusted to the requirements of the moment. The prologues of the writers of the century act as manifestos forming an ideology, wherein they state their authority and place within society (Ramos 24):

El movimiento de libertad que me tocó iniciar en América, se propagó hasta España y tanto aquí como allá el triunfo está logrado. Aunque respecto a técnica tuviese demasiado que decir en el país en donde la 
expresión poética está anquilosada a punto de que la momificación del ritmo ha llegado a ser un artículo de fe, no haré sino una corta advertencia. $[\ldots]$

Hago esta advertencia porque la forma es lo que primeramente toca a las muchedumbres. Yo no soy un poeta para muchedumbre. Pero sé que indefectiblemente tengo que ir a ellas. (Darío, Cantos ... 4)

These are discourses of a poetic identity that defends its autonomy and its singularity in relation to other previous discourses. They are the offspring of the contradictions and changes of modern society. I cannot fail to mention the "Palabras Liminares" of Prosas profanas, the "Prólogo al Poema del Niágara" (Páginas 32) and, though not in a foreword way, the poetic manifesto contained in "Mi poesía" of Martís Ismaelillo. The subjective and innovative perspective of the authors is the result of the liberalism to which they subscribe (Rama, Rubén 15) and the utilitarian selfishness they breathe. It is a behavior that sprouts from a space ruled by the fabrication, consumption, productivity and competence in which "the poet does not seem to be a need" (56). Before this decline in their social role, the poet decides to evade and engulf himself in other realities, loathing the present through an art that "no viste pantalones, ni habla en burgués, ni pone los puntos en todas las íes" (Darío, Azul 71).

In this vision, the modernista poets highlighted the existence of an "ignorant and hostile public" and a critique that ultimately ostracized them. Some poets, incapable of fighting against the bourgeois capitalist environment, denied themselves, rushing in liberal professions that were recognized legitimately as productive (Rama, Rubén 58). This happens to the character of José Fernandez: "No, Dios mío, yo no soy poeta... Soñaba antes y sueño todavía a veces en adueñarme de la forma, en forjar estrofas que sugieran mil cosas oscuras que siento bullir dentro de mí mismo y que quizás valdría la pena de decirlas, pero no puedo consagrarme a eso..." (Silva, 19). The prologue to the "Poema del Niágara" also meditates about the imprecise place of literature in a world oriented 
to productivity that does not recognize the value of the literary text in and of itself, despite it being dominated by the authority of writing. Gradually, ${ }^{7}$ the poet starts to stand out due to his individuality, starting a "literature, of universal value" (Onís 17), expressing the "sensibility of the exquisite", the "rejection to vulgarity" (Romero 290) and the conception of a world "profoundly aesthetic" (Salvador 14) which sets it apart from the critiques to fight for its professionalization.

There's a contradiction in the way of life that the urban centers pretend to engrain, as they disagree with its individualist and libertarian way of being. However, since urban centers are the place of industrialization, of cosmopolitanism and modernity, they are condemned to settle in them and adjust their attitudes accordingly. This dualistic attitude is described perfectly in the poem "El campo" by Julián del Casal with which I began this essay. The poetic "I" praises the modern city but usies adjectives that indicate a disapproving attitude, which in turn seems to recover the Latin topic of contempt of court and village praise. There is irony and censorship, but the necessity of that decadent and mystified city in the poetical frame continues to be defended.

Therefore, both the rural and the urban are mixed in new narratives that give shape to scenarios where the poetic voices or the fiction characters circulate. The intellectual is typically a citizen of the lettered city but adopts the oral traditions of both worlds (Rama, La ciudad...87), inserting all of them into a project that articulates a new autonomous discourse that explaining nationality. In concert with Ernest Renan's ideas, the geography must not mark the limits of the nation but the "spiritual principle resulting from the profound complexities of history" (81).

In the texts under consideration here, there is a demystification of the duality of civilization/barbarism associated with urban/rural spaces as them is used with a political and social weight that collects numerous contradictions. On

${ }^{7}$ Ángel Rama dates this professionalization in the years where Darío starts his poetic conquest within the Modernismo (Rubén 8). 
the one hand, the characters are conscious of the importance of the city's administration to start their projects; on the other, they return to the countryside to find the space for meditation and the roots of the origin of America:

Mira, si en mis manos estuviera te quitaría todos los refinamientos y las suntuosidad de que te rodeas, te debilitaría un poco para tranquilizarte, te pondría a vivir en un pueblecillo, en un ambiente pobre y tranquilo donde conversaras con gente del campo y no vieras más cuadros que las imágenes de la iglesia ni consiguieras más libros que el Año Cristiano, prestado por un cura. A los seis meses de vivir en ese ambiente serías otro hombre y te pondrías a escribir algún poema de los que debes escribir, de los que es tu deber escribir. (Silva 24)

Arcadia versus Babel, the rustic is exalted for its spontaneity and the quiet of its jungles and fields in contrast with the chaos and quick pace of the city. The barbaric is moved to the cosmopolitan city, to the "Babylonian threat" (Navascués 24) and creates competitive characters, dishonest nonconformists who are set in the bourgeois capital. They characterize themselves for being "more superstitious than believers, like savages", "of a fierce individualism, like the savages" and in a constant struggle, in "cannibalistic wars", with their surrounding (Blanco 254). Both scenarios are needed, and one can see the source of barbarism and the breath of the new civilization in both. In any case, the Americas at the end of the nineteenth and beginning of the twentieth century are a decadent paradise, an impressive territorial strength that isolates instead of unifying, and fights to settle in the modern architectures that are implanted progressively in the new capitals.

It follows that the new neo-imperialist order dispelled the colonial past through social, economic and urban changes imitating countries in Europe and North America. The epicenter was the city that, separated from a more provincial countryside, legitimized new citizenship discourses and new behavior guidelines that can be summarized under the sarmientian formula of civilization ahead of 
barbarism. In this context, the city was the social space to set values and standards of high culture. The realist and costumbrista literature described the new citizen, mostly bourgeois, who faced the encounter with Western modernity through instruction, travel and the fight against social prosperity which inscribed him into "civilization". Modernismo, as a regeneration movement, fed the civilizing gaps that had perpetuated beliefs and separated man from his creative nature. It was conceived as an evasion tactic but also as something sacred, which dignifies the role of the artist facing a chaotic and violent modern world. In this sense, the modernista texts built new identities that claimed their place in the bourgeoisie and urban society. Finally, in regards to discourse opposing barbarism, the writer glanced back at the original Arcadia to defend it so that, despite being a part of the lettered city, he becomes not only a son of modernity, but also of tradition, a narrative still inscribed in American geography.

\section{References}

Berman, Marshall. Todo lo sólido se desvanece en el aire. Madrid: Siglo XXI, 1988. 146. Print.

Blanco Fombona, Rufino. El hombre de hierro (novelín). Caracas: Tipografía Americana, 1874. Print.

Brenes Mesén, Roberto. Obras completas. Montevideo: Barreiro y Ramos, 1907. 663. Print.

Casal, Julián del. Bustos y rimas. La Habana: Biblioteca de la Habana Elegante, 1893. Print. 
Darío, Rubén. Antología. Edición Carmen Ruiz Barrionuevo. Madrid: Espasa, 2005. Print.

---. Azul... Prólogo de Juan Valera. Santiago de Chile: Zig-Zag, 1953. Print.

---. Cantos de vida y esperanza. Madrid: F. Granada y Cia, 1907. Print.

---. Prosas profanas. Vol. 2. Madrid: Editorial Mundo Latino, 1917. Print.

Díaz Rodríguez, Manuel. Ídolos rotos. Novela. Madrid: Editorial-América, 1919.

Print.

Fernández Retamar, Roberto. Algunos usos de civilización y barbarie. La Habana:

Letras Cubanas, 2003. Print.

González, Aníbal. La novela modernista hispanoamericana. Madrid: Editorial Gredos, 1987. Print.

González Stephan, Beatriz. "Escritura y modernización: la domesticación de la barbarie". Revista Iberoamericana. LX 166-167 (enero-junio 1994): 109-124. Print.

Gullón, Ricardo. Direcciones del Modernismo. Madrid: Editorial Gredos, 1963. Print.

Gutiérrez Girardot, Rafael. Modernismo. Supuestos históricos y culturales. México: Fondo de Cultura Económica, 1988. Print.

Lèvi-Strauss, Claude. Race et histoire. París: Presses de l’Unesco, 1958. Print.

Martí, José. Ismaelillo; Versos libres; Versos sencillos. Madrid: Cátedra 1982. Print.

---. La Edad de Oro y otros relatos. Edición de Ángel Esteban. Madrid:

Cátedra, 2006. Print.

---. Páginas selectas. Ed. Raimundo Lida. Buenos Aires: Ángel Estrada y Cía Editores, 1939. Print.

Muyolema, Armando. “De la ‘cuestión indígena' a lo ‘indígena' como cuestionamiento. Hacia una crítica del latinoamericanismo, el indigenismo y 
el mestiz(o)aje", in Ileana Rodríguez (ed.) Convergencia de tiempos: estudios subalternos/contextos latinoamericanos estados, cultura, subalternidad. Amsterdam; Atlanta: Rodopi, 2001. 351-360. Print.

Navascués, Javier de. De Arcadia a Babel. Naturaleza y ciudad en la literatura hispanoamericana. Madrid: Iberoamericana; Frankfurt am Main: Vervuert, 2002. Print.

Onís, Federico de. "La poesía hispanoamericana” Cuadernos (París) 21 (1956): 11-19. Print.

Rama, Ángel. La ciudad letrada. Hanover, NH., U.S.A.: Ediciones Norte, 1984. Print.

---. Rubén Darío y el modernismo. Caracas: Alfadil, 1985. Print.

Ramos, Julio. Desencuentros de la modernidad en América Latina. Literatura y política en el siglo XIX. Santiago de Chile: Ediciones Callejón, 2003. Print.

Renan, Ernest. “¿Qué es una nación?”. Conferencia dictada en la Sorbona el 11 de mayo de 1882. Online.

Rodó, José Enrique. Ariel. Ed. Gordon Brotherston. New York: Cambridge University Press, 1967. Print.

Romero, José Luis. Latinoamérica: las ciudades y las ideas. Buenos Aires: Siglo XXI Argentina Editores S.A., 1976. Print.

Rosenberg, Fernando. “Afecto y política de la cosmópolis latinoamericana”. Revista Iberoamericana. LXXII 215-216 (abril-septiembre 2006): 467-479. Print.

Salvador Jofre, Álvaro. El impuro amor de las ciudades (Notas acerca de la literatura modernista y el espacio urbano). La Habana: Fondo Editorial Casa de las Américas, 2002. Print.

Sarmiento, Domingo Faustino. Facundo o civilización y barbarie. Red Ediciones S.L, 2012. Online.

Silva, José Asunción. De sobremesa. Bogotá: Ediciones Sol y Luna, 1965. Print. 
CATEDRAL TomadA: Revista de crítica literaria latinoamericana / Journal of Latin American Literary Criticism Civilized Urbanity. Modernismo and the Urban Landscape.

Schulman, Ivan A. Génesis del Modernismo. México: El Colegio de México.

Washington University Press, 1966. Print.

Schütz, Eike Jacob. Ciudades en América Latina. Desarrollo barrial y vivienda. Chile: Ediciones Sur, 1987. Print.

$(\infty))$ EY ULIS D. Sale
New articles in this journal are licensed under a Creative Commons Attribution 4.0 United States License.

This site is published by the University Library System, University of Pittsburgh as part of its D-Scribe Digital Publishing Program and is cosponsored by the University of Pittsburgh Press. 